\title{
On the Role of Strategy Use and Strategy Instruction in Listening Comprehension
}

\author{
Amir Hossein Rahimi \\ Allameh Tabataba'i University, Tehran, Iran \\ Email: amh_faith@yahoo.com
}

\begin{abstract}
This paper provides a review of ideas and research regarding the role of strategy use and strategy instruction in listening comprehension. Firstly, it provides a brief explanation of different models of listening comprehension. Secondly, it sketches out different categories of learning and listening strategies. Thirdly models of strategy instruction and different attitudes towards it are reviewed. Finally, empirical studies carried out to examine the role of strategy use and strategy instruction on listening comprehension is presented.
\end{abstract}

Index Terms - listening comprehension, learning strategies, listening strategies, strategy instruction

\section{INTRODUCTION}

Long ago, listening comprehension used to be considered as a passive activity and did not merit researchers' attention (Jung, 2003; Thompson \& Rubin, 1996; Vandergrift, 2004). It had been assumed that a learner's ability to comprehend spoken language would develop entirely on its own through repetition and imitation. The focus of earlier listening comprehension materials was primarily on testing students' ability to listen to oral discourse and then answer comprehension questions based upon the incoming information (Carrier, 2003; Field, 1998). However, in the past few years the interest in teaching the listening skill has grown. Nowadays it is not regarded as a neglected skill anymore. Many people, including learners, need the listening skill in diverse settings such as school, travel, and work. Developing the listening skill is considered to be a significant goal in many language teaching courses. According to Brown (2001), listening is an important skill through which language learners internalize linguistic information without which they cannot produce language. Rubin (1994) reviewed over 130 studies and concluded there are five major factors that researchers believe affect L2 listening comprehension: (1) text characteristics, (2) interlocutor characteristics (3) task characteristics (4) listener characteristics, and (5) process characteristics. Listener characteristics include language proficiency level (knowledge of the world for cognitive processing), memory, attention, affect and background knowledge. Process characteristics include (a) Bottom up, top down and parallel processing, the use of which relates to learner proficiency level. (b) Listening strategies which are related to different strategy patterns and proficiency level. (c) Strategy training which emphasizes teaching cognitive and metacognitive strategies. These factors are closely related to learners' basic L2 proficiency level, L2 knowledge and listening comprehension strategies.

\section{A. Models of Listening Comprehension}

Three main approaches to listening comprehension include Top-down, Bottom-up and Interactive Processing which will be briefly discussed here.

The term top-down processing came originally from computer science and carried the meaning of "knowledge driven" (Field, 1999). This term is used in description of the cognitive processes of foreign language listening and foreign language reading. In Top-down processing, the learner draws upon background knowledge and expectations of what will follow next in the discourse and then infers what the intentions of the speaker may have been. Inferencing is an important part of the process, and it is important to note that the reader or listener, through the process of inferring meaning, may or may not correctly interpret the meaning of the written or spoken text (Rost, 2005). If the learner has a schema he depends upon this prior knowledge to make reasonable guesses about the meaning of the new term or structure. "Through top-down processing, readers and listeners utilize real-world knowledge and refer to various types of schemata that help them predict what will follow in the discourse" (Jung, 2003, p. 563). Schemata are constantly being created and updated, providing the reader or listener with new outlooks and new bases for interpreting texts (Rost, 2005). The listener can use this knowledge to make sense of the incoming message and to draw reasonable inferences on the meaning. There are two types of schemata, content schemata or formal schemata (Rost, 2005). Content schemata concern the actual content of the discourse, the intended message. Formal schemata concern the way discourse is organized. Both are important to the overall comprehension of the discourse.

In bottom-up processing, known from computer science as a "data-driven" process (Field, 1999), the learner analyzes the various morphosyntactic elements of the discourse, from the phonemes of the language to the syllables, words, phrases and sentences that make up the discourse. These activities require processing of all of the linguistic structures of the target language. In bottom-up processing the learner tries to match the initial sounds of a new word to his familiar 
lexicon to guess what a word might be. As more sounds occur, the listener can eliminate more and more possibilities until he arrives at the single, most accurate match to the input sounds. This matching may occur before all of the sounds have been heard because of the elimination process. Field (1999) stated that this entire process may take no more than 0.25 second, or about as long as a typical English syllable, and that the processes of analyzing and processing first phonemes, then syllables, words, phrases and finally, sentences may all occur simultaneously, or in parallel, rather than in a step-by-step process. If learners encounter input for which they have no prior knowledge, they may have to rely on bottom-up processing to supplement or to compensate for the lack of experience or knowledge of the language (Wilson, 2003 , p. 336). When learners have to rely more on bottom-up rather than top-down processing, more guesswork is involved. It is much more efficient, ultimately, if learners can rely more on processing the input by "hearing what was actually said" (p. 336).

The Interactive Process model (Park, 2004) shows how it takes both top-down processing coupled with bottom-up processing for comprehension to take place. Bottom up requires linguistic knowledge and top-down occurs when background knowledge is activated. If one or the other is missing, there can be compensation, though comprehension best takes place through the interaction of both. Top-down processing is particularly useful for lower-level learners to fill in the gaps in their bottom-up understanding of an oral text, for example when they lack proficiency in vocabulary or syntax of the L2 (Field, 1999). Top-down and bottom-up processing act in a reciprocal way. The more basic the learner, the more likely it is that s/he will rely most heavily upon bottom-up processing. In the early stages of language learning, it takes great concentration to decode the sounds of the language. The learner will need to expend great conscious effort, giving concentrated attention to the incoming stream of language, so much effort, in fact, that the learner may not have capability to focus on top-down processing. As the learner practices and rehearses this skill and becomes more proficient with the new language, comprehension of isolated sounds will become more automatic, giving the student more opportunity to activate top-down processing. At higher levels of proficiency, the two processes interact in a compensatory fashion so that what the learner misses from the bottom can be compensated for from the top as schemata become activated, and predictions are put forth and confirmed. Even in one's native language, a person doesn't actually hear every part of a message; both bottom-up and top-down processing work simultaneously to fill in the gaps as the incoming message progresses. The listener's purpose will also help to dictate which process dominates (Vandergrift, 2004). Awareness of the two processes and how the listener uses them can help the student learn how to "use both processes to [his/her] advantage, depending on [the] purpose for listening" (p. 4).

An awareness of each of these processes and their relative contribution to comprehension in different contexts and at different levels of language proficiency is fundamental to a theoretically grounded pedagogy of L2 listening comprehension. Presently, there appears to be a general consensus in the literature that listening instruction has favored the development of top-down processes at the expense of developing bottom-up processes (Vandergrift, 2004, p. 5).

\section{B. Learning Strategies}

About 1900s, language teaching stressed the importance of learning strategies. Many studies revealed that students will perform better if they use learning strategies appropriately. Learning strategies help training students to be independent and competent learners. Oxford (1990) argues that strategies are important for language learning because they are tools for active, self-directed involvement, which is essential for developing communicative competence. Learner's choice and use of language learning strategies may in a way enhance their L2 learning with effective strategies to process the input into learners' intake (Park, 1997). Learner's use of appropriate strategies enables them to be responsible for their own learning through improving their independence, self direction, and learner autonomy.

\section{Definition of Learning Strategies}

There are a lot of definitions proposed for learning strategies, with much disagreement of precisely what learning strategies are or, indeed, if they really exist. In the Concise Encyclopedia of Educational Linguistics (1999), Oxford offers this definition: Learning strategies for second or foreign language learners are "specific actions, behaviors, steps, or techniques that students use to improve their own progress in developing skills in a second or foreign language. These strategies can facilitate the internalization, storage, retrieval, or use of the new language." (p. 518)

Many researchers have attempted more simplified definitions such as the following "Strategies are the conscious actions that learners take to improve their language learning" (Anderson, 2005, p. 757). One of the main difficulties with these and other definitions is that they seem not to account for the difference between typical learning and strategic learning (Dörnyei, 2005). Dörnyei explained his belief that by adding "goal-oriented, intentionally evoked, and effortful behavior" (p.164) to definitions such as the above, we can begin to distinguish between the two concepts.

While some strategies can be readily observed, most represent mental processes. L2 learners make choices in what strategies they think best to use in particular situations. Anderson (2005) likened a learner's repertoire of strategies to that of an orchestra, with various instruments all working together to make beautiful music. Better, or more successful learners tend to use a larger repertoire of strategies than do learners with lower proficiency levels.

Dörnyei (2005) argued that, in addition, strategies encompass the concept of "appropriateness" for an individual learner or to a particular task. Even so, he acknowledged the difficulty in determining how one might determine whether and when an activity would be considered appropriate. In addition, "learning strategies... can only be defined 
relative to a particular agent, because a specific learning technique may be strategic for one and non-strategic for another..." (p. 165).

Yet another researcher has stated that "...strategies do not make learning more efficient; they are the raw material without which L2 learning cannot take place" (Macaro, 2006). Debate continues as to a precise definition, and it is hoped that ongoing research will help to elucidate the many facets of the concept of learning strategies.

\section{Categories of Learning Strategies}

Several strategies inventories have been proposed in response to various research projects. Macaro (2006) pointed out that one of the biggest areas of difficulty in the study of learning strategies centers on a lack of clarity in both definition and classification of learning strategies. The following section will present and introduce some of the most well-known taxonomies which have been proposed by scholars in the field of language learning.

One of the most comprehensive pieces of research on learning strategies was carried out by O'Malley and Chamot and colleagues in the 1980s. The final taxonomy which they came up with after several longitudinal studies consists of:

1. Metacognitive strategies: they have executive functions and include thinking about the learning process, planning for the learning, monitoring and evaluating the learning process

2. Cognitive strategies: they are utilized to directly manipulate the learning tasks at hand and are applied to specific tasks.

3. Socio-affective strategies: they have to do with interacting with others and

4. affective control to help learn the materials. (Brown, 2007, P.134)

Another very popular and frequently used strategy inventory was developed by Oxford and proposed six different categories of learning strategies. Oxford used factor analysis to group strategies into the following: Cognitive, metacognitive, memory related, compensatory, affective, and social strategies. Originally, the SILL was developed for the Defense Language Institute in California as a way to measure the language learning strategies those students used (Oxford \& Burry-Stock, 1995). The current SILL provides an 80-item version for native speakers of English who are learning a foreign language and a 50-item version for ESL/EFL students. Students respond to a series of statements about possible strategy use by choosing one of the Likert-scale numbers, $1-5$, with 1 representing "never or almost never true of me" and 5 representing "always or almost always true of me" (p. 4). The SILL has been translated into many different languages. Following are the six strategy groups with their corresponding subscales for the ESL/EFL 1990 version of the SILL:

1. Memory strategies, such as grouping, imagery, rhyming, and structured reviewing (nine items)

2. Cognitive strategies, such as reasoning, analyzing, summarizing (all reflective of deep processing), as well as general practicing (14 items).

3. Compensation strategies (to compensate for limited knowledge), such as guessing meanings from the context in reading and listening and using synonyms and gestures to convey meaning when the precise expression is not known (six items).

4. Metacognitive strategies, such as paying attention, consciously searching for practice opportunities, planning for language tasks, self-evaluating one's progress, and monitoring error (nine items).

5. Affective (emotional, motivation-related) strategies, such as anxiety reduction, self-encouragement, and selfreward (six items).

6. Social strategies, such as asking questions, cooperating with active speakers of the language, and becoming culturally aware (six items). (Oxford \& Burry-Stock, 1995, p.5)

Macaro (2001) classified strategies on a continuum with, at one end, cognitive strategies and at the other, metacognitive/social/affective. Following the same pattern, he placed along with cognitive, subconscious, direct, automatized, difficult to articulate, non-evaluative, primary, and natural. Along with metacognitive / social / affective, he included conscious, indirect, controlled, easier to articulate, evaluative, support, and taught (p. 24). Those falling at the cognitive side are closely related to the task at hand while those falling more at the metacognitive / social / affective side are more related to the learner's self-preparation to complete the task. Learners may be able to better articulate what happens in these latter strategy types than they can in the more cognitive ones. We are reminded that this classification falls on a continuum, so many strategies fall somewhere in-between the two extremes in each grouping. Examples (direct, subconscious) might include the following:

1. Linking words or ideas to visual images as you see them or hear them" (more cognitive

2. Memorizing a list of vocabulary items by using some sort of system" (mid- range of continuum)

3. Asking the teacher for clarification or to repeat something they didn't "quite catch (more metacognitive/social/affective)" (p. 25).

In his more recent work, Macaro (2006) preferred to classify learning strategies as either cognitive or metacognitive, claiming that metacognitive subsumes the socio-affective domains. Macaro presented his belief that strategies always include a goal. That goal may have origin with the learner, as in the learner's self-imposed desire to master a certain concept, for example, or it may have a teacher-imposed goal, as in the necessity to pass a test. In his explanation of how learning takes place in relation to strategy use, Macaro chose to identify and investigate strategy clusters, which can include activation of several interrelated or sequential strategies. This concept of strategy clusters was followed in interventions presented in this study. 
In an attempt to bring different categorizations of strategies together, Dornyei (2005) proposed a typology with four types of strategies:

1. Cognitive strategies, involving the manipulation or transformation of the learning materials/input (e.g., repetition, summarizing, using images).

2. Metacognitive strategies, involving higher-order strategies aimed at analyzing, monitoring, evaluating, planning, and organizing ones' own learning process.

3. Social strategies, involving interpersonal behaviors aimed at increasing the amount of L2 communication and practice the learner undertakes (e.g., initiating interaction with native speakers, cooperating with peers).

4. Affective strategies, involving taking control of the emotional (affective) conditions and experiences that shape one's subjective involvement in learning. (p. 169).

\section{E. Listening Strategies}

Listeners make use of a variety of strategies to make sense of the incoming messages and compensate for their lack of knowledge especially in EFL contexts. Listening Strategies which are employed by language learners are relatively the same as general learning strategies discussed in the previous section.

Vandergrift (1997b) taxonomy is based on O’Malley and Chamot (1990, 137-139); Oxford (1990, 21); Vandergrift (1996). He proposed three types of strategies, metacognitive, cognitive, and socio-affective.

Field's (2008) taxonomy draws upon Dornyei and Scott and adapts their list of strategies to make them refer to listening strategies. Some new strategies have been added by him too. His taxonomy of listening strategies involves:

1. Avoidance strategies: learner gets by without the missing or uncertain piece of input.

2. Achievement strategies: learner attempts to make maximum sense of what has been decoded.

3. Repair strategies: learner appeals for help.

4. Pro-active strategies: learner plans her behavior in away that might enable problems of understanding to be avoided. (Field, 2008, p.298)

\section{F. Teaching Listening Strategies}

Until recently, most research focused on discovering and categorizing the types of learning strategies used in language learning or the differences between strategy uses in successful language learners as compared to those of less successful learners (Chamot, 2005). The focus has shifted to research into ways to teach effective strategy use. Information that has been gathered from descriptive studies is now being used to "measure relationships between strategy use and language proficiency, metacognition, motivation, and self-efficacy" (Chamot, 2005, p. 115).

Researchers disagree on whether or not learning and listening strategies should be actively taught to L2 learners. Several researchers believe that the research is, in fact, indefinite as to whether instruction in strategies really produces any positive effect for learners (Chamot, 1995; Rubin, 1994) though it should be noted that this type of research is very difficult to conduct and results may not be clear. For example, in a study of student success in developing and using learning strategies (Thompson \& Rubin, 1996), it was found that L2 students did show some improvement in their use of strategies incomprehension of videotaped materials. However, the study did not show a positive correlation between strategy instruction and learner performance. In addition, no distinction was made between those strategies intended to assist in extracting meaning and those intended for learning a new language. A study of how raising awareness of the strategies L2 speakers can use showed that those learners who were given instruction in strategies for oral communication realized greater improvement in their speaking abilities than did the control group, which did not receive strategies instruction (Nakatani, 2005). Other studies have also shown that intervention, the teaching of strategies, has been beneficial for L2 learners (McGruddy, 1998; O’Malley \& Chamot, 1990; Ross \& Rost, 1991; Thompson \& Rubin, 1996).

Even among those researchers who believe strategies should be taught, there is disagreement about in what context that should occur. Is it better to teach strategies as part of the ESL or foreign language curriculum, or might it be better to provide a course of strategy instruction in isolation? There is concern about whether or not students will transfer what they have learned into real-world learning. Chamot (2004) proposed that "teachers should opt for explicit instruction and should probably integrate the instruction into their regular course work, rather than providing a separate learning strategies course" (p.19). Further, she advised teachers in all content courses to learn about and actively teach students the strategies they would need to succeed in those courses. Despite results from early studies showing that strategies did not seem to transfer to new learning situations, more recent studies have shown that when metacognitive strategies are prioritized, transfer does occur.

Rubin (1996) focused on three approaches in teaching strategy use: raising teacher awareness so that instructors can be more effective in teaching strategies, providing learners text-based instructional materials, and using media-based instruction. Rubin's 1989 Language Learning Strategies Program relied on computer and video disk input to help learners identify successful learning strategies.

An important component of strategy instruction is the increase in students' awareness of the background knowledge they bring to the task. Many learners fail to realize that they already know a great deal about grammar, vocabulary, and communication. They often do not know how to transfer that knowledge to learning another language. Students may not realize they can use what they know about the world and about human interaction to direct their critical thinking and 
problem solving. Learners need to be reminded how they filter information through that which they already know, as well as how this filter can help or hinder as they learn a new communicative system. (Rubin, 1996, p. 152)

A number of studies have shown increases in various categories of learning strategy use as a result of instruction (Chamot \& O’Malley, 1996; Goh, 1998; Goh, 2002a; McGruddy, 1998; Rubin, 1996; Yang, 1996).

Even when students have been instructed in listening strategies, problems can be created. A definition for the term "listening strategy" (Chen, 2005) states: "L2/FL learning and strategy learning are considered to be the learning of complex cognitive skills." even though a second language listener might actually know a vocabulary item or phrase, s/he might not recognize that item when it is presented in a stream of speech. As an alternative to the teaching of strategies like predicting or listening for key terms, giving listeners opportunities to listen over and over, each time adding to what they have been able to identify and then giving them access to a written script so that they can compare their hypotheses to the actual, may help L2 listeners to feel more comfortable with their listening tasks. The goal is to show students how much they are able to understand rather than allowing them to focus on their failure to understand. This process is very like the actual process of listening and comprehending aural discourse.

Proponents of active teaching of both learning and listening strategies (Arnold, 2000; Field, 1998; Flowerdew \& Miller, 2005; Goh, 1998; Harley, 2000; Morley, 2001; Park, 2000; Thompson and Rubin, 1996; Vandergrift, 1999, 2002) base their beliefs on various pieces of research. L2 learners, research shows, do benefit from being actively taught do use various strategies as they approach listening tasks. Proponents believe instructors must be well-trained in as well as committed to instructing use of strategies. Mendelsohn (1995) offered the premise that it is a listening instructor's responsibility to teach students to use strategies rather than simply provide opportunities for students to listen to oral passages

\section{G. Models of Listening Strategy Instruction}

There are various issues related to strategy instruction in the literature. O'Malley and Chamot (1990) discussed about these issues in their seminal book ' learning strategies in second language acquisition'. A controversy which exists in instruction in learning strategies is whether instruction should focus on learning strategy instruction or should be integrated with classroom instruction. Some scholars believe that students can generalize the strategies to other contexts and they learn better when they put all their effort on developing strategic skills rather than trying to learn the content at the same time, so the best way to teach learning strategies is to design a separate program or course to implement strategy instruction. Another group of researchers are in favor of integrated strategy instruction. They argue that when students practice strategies by performing academic and language tasks, transference of those skills and strategies to similar tasks and similar contexts will be more easily and successfully done. There is a third group which is in favor of integrating both approaches which were discussed above (Dansereau, 1985; cited in O'Malley \& Chamot ,1990, p.153; Derry, 1984 cited in O'Malley \& Chamot ,1990, p.153).

Another dichotomy which is discussed by O'Malley and Chamot (1990) is direct versus embedded instruction. They state that "in direct instruction, students are informed of the value and purpose of strategy training, whereas in embedded instruction, students are presented with activities and materials structured to elicit the use of the strategies being taught but are not informed of the reasons why this approach to learning is being practice" (p.153). An advantage mentioned for embedded strategy training is that little teacher training is required. The results of studies has shown that students which are trained using embedded approach can not transfer the skills and strategies to new tasks ( Brown, Armbruster, \& Baker, 1986 cited in O'Malley \& Chamot, 1990, p.153). When the purpose and importance of the strategies are explained to the students, a metacognitive component, students are able to maintain and use strategies for longer period of time and transfer it to the new tasks (Brown et al. 1986; Palincsar and Brown, 1986 cited in O'Malley \& Chamot,1990, p.153 ). Many researchers recommend direct strategy training over embedded one.

An instructional model for strategy training which is discussed by O'Malley and Chamot (1990) is 'the strategy teaching model' developed by Jones et al. (1987). This model is based on six assumptions:

1. Learning is goal oriented. Expert learners have two major goals during the learning process: to understand the meaning of the task and to regulate their own learning. In other words, learners have both declarative knowledge, or content goals, and procedural knowledge, or strategic goals for a learning task.

2. In learning, new information is linked to prior knowledge. Prior knowledge is stored in memory in the form of knowledge frameworks or schemata, and new information is understood and stored by calling up the appropriate schema and integrating the new information with it. Knowing how and when to access prior knowledge is a characteristic of effective learners.

3. Learning requires knowledge organization. Knowledge is organized in recognizable frameworks such as story grammars, problem/solution structures, comparison/contrast patterns, and description sequences, among others. Skilled learners recognize these organizational structures and use them to assist learning and recall.

4. Learning is strategic. Good learners are aware of the learning process and of themselves as learners, and seek to control their own learning the use of appropriate learning strategies. Strategies can be taught, but many do not transfer to new tasks. Although each content area may require a particular set of strategies and skills, a number of core skills underlie all subject areas. Examples of these core skills are using prior knowledge, making a representation of the information, self monitoring, and summarizing. 
5. Learning occurs in recursive phases. All types of learning are initiated with a planning phase, followed by online processing, and ending with consolidation and extension of the new information. In the planning phase, the problem is identified, goals are set, and prior knowledge is activated. During on-line processing new information is integrated, assimilated, and used to clarify or modify existing ideas. During consolidation and extension the learner summarizes and organizes the new information, assesses achievement of the goal established in the first phase, and extends learning by applying it to new situations. During each phase the learner may return to a previous phase to rework one or more of its aspects.

6. Learning is influenced by development. Differences between older and younger students and between more and less proficient learners are due in large part to differences in prior knowledge and learning strategy use. These differences may be present when children begin school or may develop over time, but in either case they tend to persist unless intervention is undertaken. (Jones, Palincsar, Ogle \& Carr,1987 cited in O'Malley \& Chamot,1990, p.187-188)

In this model the specific sequence which is suggested for instruction is: assessing students' current strategy use, explaining the new strategy, modeling the strategy and providing scaffolding when students practice using strategies for the first time. O'Malley and Chamot (1990) elaborate on three phases that teachers go through for instruction. In the preparation phase the teacher activates students' prior knowledge of the lesson topic through questioning, evaluating the relevance of the prior knowledge, and refining that knowledge. During this phase students can also preview the new information to be learned, develop new vocabulary, and identify concepts or beliefs that may be changed or replaced after instruction. In the presentation phase of the lesson, students interact with the new information presented by the teacher or text through selecting, comparing, organizing, and integrating activities. Reciprocal teaching, in which students and teacher cooperate to understand a text by taking turns to apply a sequence of comprehension strategies. The application and integration phase of the strategic lesson serves the dual purposes of evaluating and consolidating the learning task. To evaluate their learning, students refer back to their original goals that were established during the preparation phase. In doing so they consolidate the new information by using it to restructure their prior knowledge, identified in the preparation phase. (p.189)

Another well-known model which is proposed for strategy training is 'cognitive academic language learning approach'. Chamot and O'Malley (1987) state that this model is designed to meet the needs of three types of students:

1. Students who have developed social communicative skills through beginning level ESL classes or through exposure to an English-speaking environment, but have not yet developed academic language skills appropriate to their grade level;

2. Students who have acquired academic language skills in their native language and initial proficiency in English , but who need assistance in transferring concepts and skills learned in the first language to English and

3. Bilingual English-dominant students who have not yet developed academic language skills in either language. (p. 229)

This model is based on the cognitive theory in which language is viewed as a complex skill. Learners should pass through certain stages to move from declarative to procedural knowledge. Learning in this view is seen as movement from controlled to automatic processing via practice. Anderson's (1983, 1985) ACT model is a processing model from cognitive psychology which suggests that acquiring a language (movement from declarative to procedural knowledge) takes place in three stages: the cognitive, the associative, and the autonomous stages. (Cited in O'malley and Chamot ,1990,p.162). O'Malley and Chamot (1990) argue that this approach "provides useful insights into the academic language needs of LEP students, which CALLA is intended to meet" (p.192). The CALLA includes three components: topics from the major content subjects, development of academic language skills, and direct instruction in learning strategies for both content and language. Our focus is on the third component, strategy instruction. Chamot and O'Malley (1987) express that strategy instruction in CALLA is based on four arguments:

1. Mentally active learners are better learners. Students who organize new information and consciously relate it to existing knowledge should have more cognitive linkages to assist comprehension and recall than do students who approach each new task as something to be memorized by rote learning.

2. Strategies can be taught. Students who are taught to us strategies and provided with sufficient practice in using them will learn more effectively than students who have had no experience with learning strategies.

3. Learning strategies transfer to new tasks. Once students have become accustomed to using learning strategies, they will use them on new tasks that are similar to the learning activities on which they were initially trained.

4. Academic language learning is more effective with learning strategies. Academic language learning among students of English as a second language is governed by some of the same principles that govern reading and problem solving among native English speakers. (p.240)

General guidelines for learning strategy instruction in CALLA model are as follows: at first, teachers find out what strategies the students are already using. It can be done through interviews or think-aloud procedure. Next, the teacher can select some new strategies which are not utilized by the students. In the presentation phase, teachers explain the purpose of the learning strategies, name the strategies to be taught, and explain about the advantages of using them. The explanation of the strategies should be tailored to the proficiency level of students. Then teachers model the strategy use by performing a task. Teachers should provide the students with a variety of activities and tasks to practice the strategy use. The next stage is to enable students to learn how to evaluate their own strategy use. This can be done through 
writing the strategies after completing a task, discussing about the strategies used for tasks, keeping dialogue journals and etc. Finally, teachers help students to transfer the strategies to new contexts.

Another model of strategy instruction is proposed by Vandergrift (2004) and Vandergrift and Tafaghodtari (2010). Vandergrift and Tafaghodtari (2010) explain about stages of strategy instruction in this model:

Prelistening: Planning/predicting stage

1. After students have been informed of the topic and text type, they predict the types of information and possible words they may hear.

First listen: First verification stage

2. Students verify their initial hypotheses, correct as required, and note additional information understood.

3. Students compare what they have understood/written with peers, modify as required, establish what still needs resolution, and decide on the important details that still require special attention.

Second listen: Second verification stage

4. Students verify points of earlier disagreement, make corrections, and write down additional details understood.

5. Class discussion in which all class members contribute to the reconstruction of the text $\mathrm{s}$ main points and most pertinent details, interspersed with reflections on how students arrived at the meaning of certain words or parts of the text.

Third listen: Final verification stage

6. Students listen specifically for the information revealed in the class discussion which they were not able to decipher earlier.

Reflection stage

7. Based on the earlier discussion of strategies used to compensate for what was not understood, students write goals for the next listening activity

\section{H. Empirical Studies on Listening Strategies}

Murphy (1985) used a think aloud procedure to study the listening strategies of effective and less effective ESL learners. He found that effective learners used more strategies and a greater variety of strategies. But less effective learners concentrate too much on the text or their own knowledge. At that time the categorization of learning strategies had not been done yet, so Murphy did not distinguish between metacognitive and cognitive and other kinds of strategies.

Rubin (1988 cited in vandergrift, 1999) investigated the effect of strategy instruction on the comprehension of video by Spanish high school students. The performance of three experimental groups was compared with the two control groups. Rubin found that the use of some strategies (e.g. storyline) can help students in successful comprehension of difficult materials. He concluded that "the combination of well selected video and the acquisition of effective learning strategies can improve student affect and motivation" (p. 32).

Chamot and Kupper (1989) used a think aloud procedure and examined the listening strategies of high school learners. They found that effective learners used more strategies than less effective learners. They used the strategies, like note taking, selective attention, and self-evaluation with greater persistence. Chamot and Kupper examined the strategy use of Russian students too. They found that effective listeners used four categories of strategies more than others, they include: comprehension monitoring, problem identification, inferencing, elaboration

O'Malley, Chamot and Kupper (1989) investigated the pattern of strategy use of high school intermediate learners. They concluded that effective listeners can keep their concentration, back on the track when distracted and they decide what to attend beforehand. They try to make a connection between what they already know and what they listened. They use the cues in the context and their personal experience. On the other hand less successful listeners did not make fewer use of their background knowledge. They lose their concentration easily when encountering a problem. Effective learners used inferencing, self monitoring and elaboration more.

Using a think aloud procedure, Bacon (1992a, 1992b) examined the strategy use of male and female university students learning Spanish. She observed that the factors which play role in successful listening are: motivation, use of background knowledge, self control, maintaining attention and using a variety of strategies flexibly. She also found that the learners used more cognitive strategies. Female students made use of metacognitive strategies more than males. She noticed that effective and less effective learners used monitoring equally but effective learners were more realistic.

Using a structured interview, Vandergrift (1996) examined the types and numbers of strategy used by core French students. Students were at different course levels. He concluded that three categories of strategies could be distinguished; cognitive, metacognitive, socio affective. Students reported more cognitive strategies than the other categories. As the course level increased the total number of strategies reported increased too. The same pattern was observed for metacognitive category. Females reported using more metacognitive strategies compared to males. Reported use of socio-affective strategies increased by course level too.

In a longitudinal study, using video segments from simulated authentic materials, Thompson and Rubin (1996) investigated the effect of strategy instruction on the listening comprehension performance of university students learning Russian. The performance of an experimental group was compared to a control group which received no strategy instruction. The result of the pre and post test showed that students who received strategy instruction improved significantly over those who did not receive such instruction. It was demonstrated that metacognitive strategies helped students to manage their approach to listening. 
Goh (1997) investigated Chinese students' metacognitive knowledge in L2 listening comprehension. The students were asked to keep a diary about their listening. Some questions were designed to help students in reflecting on specific occasions where they listened to English and report what they did to understand better. They were also asked to include their thoughts about learning to listen, and to say how they practiced their listening after class. The students' beliefs and observations were classified under person knowledge, task knowledge, and strategic knowledge. Analysis of the diaries demonstrated that the students reported extensively on all three types of metacognitive knowledge. Goh (1997) stated that "The listening diaries demonstrated that the students had a high degree of metacognitive awareness. They were conscious of their learning process and the demands of listening to English, and had specific beliefs about the factors that could enhance or impair their listening comprehension" (p.367)

In another study, Vandergrift (1997) investigated the strategy use of novice and intermediate level of French students. He concluded that novice learners relied heavily on elaboration, transfer, and inferencing. Novice level students overcome the limited knowledge by using extra linguistic cues and cognates. On the other hand intermediate level learners used over twice as many metacognitive strategies as the novice-level learners.

Using retrospective verbal data, Goh (2002a) investigated the listening strategies and tactics used by a group of ESL learners. Participants were male and female students, aged between 18 and 19, from the People's Republic of china. Two students, one more proficient listener and one less proficient were selected for further analysis and comparison of tactic used and interaction. Goh (2002) identified a total of 44 different tactics used by the learners: 22 cognitive tactics grouped under eight cognitive strategies and 22 metacognitive tactics grouped under six metacognitive strategies. She found that both learners used a combination of listening tactics when processing individual segments of the text. Both used metacognitive and cognitive tactics and both engaged in top-down and bottom-up processing. However, there were some differences between the two learners. The more-proficient listener used a wider range of tactics while the lessproficient listener used more low level tactics. Goh concluded that "although individual tactics were useful, successful comprehension also depended on whether the listener was able to combine various mental tactics in a way that could truly enhance comprehension" (2002, p. 203).

Carrier (2003) taught listening comprehension strategies, focusing on academic listening tasks. The participants were a small group of high school ESL students. This study took six weeks and included both bottom-up and top-down approaches to listening. The strategies which were taught involved selective attention and note taking. First the teacher defined and modeled the strategies then provided the students with opportunity to practice. The result of pre-test and post-test revealed that students significantly improved both bottom-up and top-down approaches.

Vandergrift (2003a) made use of tasks designed to develop effective listening strategies to raise awareness of FSL university students about listening process. The instruction was as follows: after being informed of the topic of the lesson, students wrote their prediction and related vocabulary about the information they might hear. Then they listened to the aural text for the first time and saw whether their predictions were right. Next they discussed about what they had understood. The students listened to the text for the second time and wrote additional information. This was followed by class discussion in which students shared the strategies they had used to comprehend the text. After a third listening, students wrote a personal reflection on what they had learned about their own listening processes and what strategies they might use in future to improve listening comprehension. Students' written reflections revealed positive reactions to the strategies, increased motivation, and understanding of their own thinking processes during listening tasks.

Vandergrift (2003b) compared the listening comprehension strategies of more- and less-skilled Canadian seventhgrade students of French. Students listened to several French texts and were asked to think aloud during the process. The more skilled listeners used more metacognitive strategies, especially comprehension monitoring, than did their less skilled peers. In addition, more skilled listeners engaged in questioning for clarification, whereas the less skilled used more translation.

Goh and Taib (2006) utilized eight specially designed listening lessons that included traditional listening exercises, individual post-listening reflections on their listening experience, and teacher-facilitated discussions that focused on specific aspects of metacognitive knowledge about listening to teach metacognitive strategies to ten primary school pupils. After the eight lessons, the students reported a deeper understanding of the nature and the demands of listening, increased confidence in completing listening tasks, and better strategic knowledge for dealing with comprehension difficulties. The weaker learners have benefited the most from this process-based approach to listening instruction.

Graham et al (2008) examined the development of strategy use over 6 months in two lower-intermediate learners of L2 French in secondary schools in England. Strategic behavior of these two learners was investigated through verbal reports made by them while completing a multiple-choice listening task. The results revealed a high degree of stability of strategy use over the time period, with pre-existing differences between the high and low scorer persisted.

Graham and Macaro (2008) investigated the effects of strategy instruction on the listening performance and selfefficacy of 68 lower-intermediate learners of French in England. The effects of high- and low-scaffolded interventions were also compared. Result represented that the program improved listening proficiency and learners' confidence about listening.

Vandergrift and Tafaghodtari (2010) investigated the effects of a metacognitive, process-based approach to teaching second language (L2) listening. The participants were 106 students of French as an 12. 59 students were assigned to experimental group. They listened to a variety of texts and were taught metacognitive processes including prediction, 
planning, monitoring, evaluating and problem solving. The control group included 47 students who listened to the same texts without metacognitive instruction. The experimental group outperformed the control group in the listening comprehension measure. Less skilled listeners in the experimental group made greater gains than their more skilled ones.

\section{CONCLUSION}

Teachers may need to introduce the concept of language learning strategies to students and make students familiar with the learning strategies. They may need to provide instruction and practice in using strategies, which have positive influence on their performance. Foreign language teachers should be engaged in an ongoing process of determining the kinds of strategies which have potential for improving students' listening ability. As Oxford et al. (1989) has suggested, it is important to teach learners clearly why and how to use strategies in appropriate situations. It is necessary for teachers to provide learners with opportunities to practice the new strategies so as to integrate them into the process of language learning. Learners themselves can apply the strategies while working on different listening tasks and activities. Using listening strategies increases their awareness about the listening process, which leads to better performance. By practicing listening strategies, learners become self-regulated listeners and can succeed in accomplishing different tasks with different levels outside the classroom contexts. More research evidence has confirmed the positive influence of strategy instruction on developing listening; therefore, incorporating strategy-based tasks and activities in listening textbooks becomes an urgent need. Materials developers should allocate specific sections of listening materials to introduce the concept of strategies.

\section{REFERENCES}

[1] Anderson, N. J. (2005). Learning strategies. In E. Hinkel, Handbook of research in second language teaching and learning (pp. 757-771). Mahwah, NJ:: Lawrence Erlbaum Associates, Inc.

[2] Arnold, J. (2000). Seeing through listening comprehension anxiety. TESOL Quarterly, 34, 777-786.

[3] Bacon, S.M. (1992a). The relationship between gender, comprehension, processing strategies, and cognitive and affective response in foreign language listening. Modern Language Journal, 76, 160-178.

[4] Bacon, S. M. (1992b). Phases of listening to authentic input in Spanish: a descriptive study. Foreign Language Annals, 25, 317-334.

[5] Brown, H. D. (2001). Teaching by principles: An interactive approach to language pedagogy (2nd ed.). White Plains, NY: Pearson Education.

[6] Brown, H. D. (2007). Principles of language learning and teaching (5th ed.). New York: Pearson Education.

[7] Carrier, K. A. (2003). Improving high school English language learners' second language listening through strategy instruction. Bilingual Research Journal, 27, 383-410.

[8] Chamot, A.U. (1995). Learning strategies and listening comprehension. In Mendelsohn and Rubin (Eds.) A guide for the teaching of second Language listening (pp.18-24). San Diego: Dominic Press.

[9] Chamot, A. U. (2004). Issues in language learning strategy research and teaching. Electronic Journal of Foreign Language Teaching, 1, 14-26.

[10] Chamot, A. U. (2005). Language learning strategy instruction: Current issues and research. Annual Review of Applied Linguistics, 25, 112-130.

[11] Chamot, A. U., \& Kupper, L. (1989). Learning strategies in foreign language instruction. Foreign Language Annals, 22, $13-24$.

[12] Chamot, A.U. \& O'Malley, J.M. (1987). A cognitive academic language learning approach: A bridge to the mainstream. TESOL Quarterly, 21, 227-49.

[13] Chamot, A. U., \& O’Malley, J. M. (1996). Implementing the cognitive academic language learning approach (CALLA). In Oxford, Language learning strategies around the world: Cross-cultural perspectives (Technical Report \#13) (pp. 167-173). Honolulu, HI: University of Hawai'i, Second Language Teaching \& Curriculum Center.

[14] Dörnyei, Z. (2005). The psychology of the language learner: Individual differences in second language acquisition. Mahwah, NJ: Lawrence Erlbaum Associates.

[15] Field, J. (1998). Skills and strategies: Towards a new methodology for listening. ELT Journal, 52, 110-118.

[16] Field, J. (1999). Key concepts in ELT: "bottom-up" and "top-down". ELT Journal, 9, 29-34.

[17] Field, J. (2008). Listening in language classroom. Cambridge: Cambridge University Press.

[18] Flowerdew, J., \& Miller, L. (2005). Second language listening: Theory and practice. New York: Cambridge University Press.

[19] Goh, C. C. (1997). Metacognitive awareness and second language listeners. ELT Journal, 51, 361-369.

[20] Goh, C. C. (1998). How ESL learners with different listening abilities use comprehension strategies and tactics. Language Teaching Research, 2, 124-147.

[21] Goh, C. C. (2002). Exploring listening comprehension tactics and their interaction patterns. System, 30, 185-206.

[22] Goh, C. \& Y. Taib. (2006). Metacognitive instruction in listening for young learners. ELT Journal, 60, 222-232.

[23] Graham, S., Santos, D., \& Vanderplank, R. (2008). Listening comprehension and strategy use: A longitudinal exploration. System, 36, 52-68.

[24] Harley, B. (2000). Listening strategies in ESL: Do age and L1 make a difference? TESOL Quarterly, 34, 769-777.

[25] Jung, E. H. (2003). The role of discourse signaling cues in second language listening comprehension. The Modern Language Journal, 87, 562-577.

[26] Macaro, E. (2001). Learning strategies in foreign and second language classrooms. New York: Ernesto Macaro.

[27] Macaro, E. (2006). Strategies for language learning and for language use: Revising the theoretical framework. The Modern Language Journal, 90, 320-337. 
[28] McGruddy, R. (1998). The effect of listening comprehension strategy training with advanced level ESL students. Dissertation Abstracts International, 59, 4416, (UMI No. 9916234).

[29] Morley, J. (2001). Aural comprehension instruction: Principles and practice. In M. Celce-Murcia, Teaching English as a second or foreign language (3rd ed.) (pp. 69-85). Boston: Heinle \& Heinle.

[30] Murphy, J. M. (1985). An investigation into the listening strategies of ESL college students. ERIC document Reproduction Service No. ED 278275.

[31] Nakatani, Y. (2005). The effects of awareness-raising training on oral communication strategy use. The Modern Language Journal, 89, 76-91.

[32] O’Malley, J. M., \& Chamot, A. U. (1990). Learning strategies in second language acquisition. Cambridge, UK: Cambridge University Press.

[33] O'Malley, M. J., Chamot, A. U., \& Kupper, L. (1989). Listening comprehension strategies in second language acquisition. Applied Linguistics, 10, 418-437.

[34] Oxford, R. L. (1990). Language learning strategies: What every teacher should know. Boston MA: Heinle \& Heinle.

[35] Oxford, R. L., \& Burry-Stock, J. A. (1995). Assessing the use of language learning strategies worldwide with the ESL/EFL version of the Strategy Inventory for Language Learning (SILL). System, 23, 1-23.

[36] Oxford, R.L., Saunders, D., \& Lavine, R.Z. (1989). Language learning strategies, the communicative approach, and their classroom implications. Foreign Language Annals, 22, 29-39.

[37] Park, G. E. (1997). Language learning strategies and English proficiency in Korean university students. Foreign Language Annals, 30, 211-221

[38] Park, G. E. (2000). The effect of question presentation and question type on listening comprehension. English Teaching, 55, 141-156.

[39] Park, G.E. (2004). Comparison of L2 listening and reading comprehension by university students learning English in Oxford, R. L. (1999). Learning strategies. In B. Spolsky, Concise encyclopedia of educational linguistics (pp. 518-522). Oxford: Elsevier.

[40] Rost, M. (2005). L2 listening. In E. Hinkel, Handbook of research on second language learning and teaching (pp. 503-527). Mahwah, NJ: Erlbaum.

[41] Ross, S., \& Rost, M. (1991). Learner use of strategies in interaction: Typology and teachability. Language Learning, 41, 235273.

[42] Rubin, J. (1994). A review of second language listening comprehension research. Modern Language Journal, 78, $213-215$.

[43] Rubin, J. (1996). Using multimedia for learner strategy instruction. In Oxford, Language learning strategies around the world: Cross-cultural perspectives (Technical Report \#13) (pp. 151-156). Honolulu, HI: University of Hawai'i, Second Language Teaching \& Curriculum Center.

[44] Thompson, I. \& Rubin, J (1996). Can strategy instruction improve listening comprehension? Foreign Language Annals, 29, 331-342.

[45] Vandergrift, L. (1996). Listening strategies of Core French high school students. Canadian Modern Language Review, 52, 200-223.

[46] Vandergrift, L. (1997). The comprehension strategies of second language (French) listeners: A descriptive study. Foreign Language Annals, 30, 387-409.

[47] Vandergrift, L. (1999). Facilitating second language listening comprehension: acquiring successful strategies. ELT Journal, 53, 168-176.

[48] Vandergrift, L. (2002). It was nice to see that our predictions were right: Developing metacognition in L2 listening comprehension. The Canadian Language Review, 58, 555-575.

[49] Vandergrift, L. (2003a). Orchestrating strategy use: Towards a model of the skilled L2 listener. Language Learning, 53, 461494.

[50] Vandergrift, L. (2003b). From prediction through reflection: Guiding students through the process of L2 listening. The Canadian Modern Language Review, 59, 425-440.

[51] Vandergrift, L. (2004). Listening to learn or learning to listen? . Annual Review of Applied linguistics, 24, 3-25.

[52] Vandergrift, L., \& Tafaghodtari, M. (2010). Teaching L2 Learners How to Listen Does Make a Difference: An Empirical Study. Language Learning, 60, 470-467.

[53] Wilson, M. (2003). Discovery listening-improving perceptual processing. ELT Journal, 57, 335-343.

[54] Yang, N.-D. (1996). Effective awareness-raising in language learning strategy instruction. In Oxford, Language learning strategies around the world: Cross-cultural perspectives (Technical Report \#13) (pp. 205-210). Honolulu, HI: University of Hawai'i, Second Language Teaching \& Curriculum Center.

Amir Hossein Rahimi holds an MA degree in TEFL from Allameh Tabataba'i University in Tehran, Iran. He has taught general English courses at payamnour and shahid beheshti university. His research interests lie in cooperative learning and investigation of language learning strategies. 